\title{
Reaction of Metals with Floor Cleaner Liquids
}

Siti Rahmah", Elsima Nainggolan, Aura F Harahap, Cut S Riska, Deri S Sitepu, Anna C Siregar, Aria Nanda, Debora P Simanjuntak

Chemistry Department, Faculty of Mathematics and Natural Sciences, Universitas Negeri Medan, Medan 20221, Indonesia

*Email : rahmah.siti@unimed.ac.id

\begin{abstract}
Metals react with acid to produce hydrogen gas. Some of floor cleaner liquids contain concentrated strong acid such as $\mathrm{HCl}$. This study was conducted to react metals (Zn, Al, Fe, $\mathrm{Cu}$ ) with floor cleaner liquids (WPC and Vixal) that contain $17 \% \mathrm{HCl}$ to produce hydrogen gas. The most hydrogen gases were resulted from reaction between Al and both of floor cleaner liquids. They show the same trend $\mathrm{Al}>\mathrm{Cu}>\mathrm{Zn}>\mathrm{Fe}$ for the volume of hydrogen gas produced. It was not appropriate with theory due to different of surface area of each metals used.
\end{abstract}

Keywords: Metal, Hydrogen, Floor Cleaner Liquid.

\section{Pendahuluan}

Gas hidrogen dapat diproduksi melalui berbagai metode. Menurut ${ }^{1}$ Holladay, et al. (2009) Kebanyakan produksi gas hidrogen yang dilakukan saat ini adalah melalui reaksi elektrolisis dan reformasi minyak dan biomassa. Gas hidrogen merupakan sumber energi alternatif masa depan yang ramah lingkungan ${ }^{2}$. Sehingga, banyak penelitian terkait produksi gas hidrogen.

Reaksi logam dengan air menghasilkan gas hidrogen, khususnya bagi logam-logam alkali seperti $\mathrm{Li}, \mathrm{Na}, \mathrm{K}$. karena reaktivitasnya yang sangat tinggi. Sedangkan logam Al merupakan logam yang spesial karena dapat menghasilkan gas hidrogen dari reaksi $\mathrm{Al}$ dengan basa kuat seperti $\mathrm{KOH}$ dan $\mathrm{NaOH}^{3} \mathrm{Al}$ mengalami reaksi oksidasi membentuk lapisan oksida tipis $\mathrm{Al}_{2} \mathrm{O}_{3}$ yang mencegahnya dari serangan molekul air secara langsung ${ }^{4}$. Gas hidrogen juga bisa dihasilkan melalui reaksi antara logam dengan asam-asam Arhenius seperti $\mathrm{HCl}$, dan $\mathrm{H}_{2} \mathrm{SO}_{4}$.
Cairan pembersih lantai yang dijual dipasaran terdiri dari berbagai merek yaitu WPC, Vixal, Wipol Karbol, Porstek, dan lain lain. Cairan pembersih lantai dengan merek WPC dan Vixal mengandung asam kuat $\mathrm{HCl}$ sebagai zat adiktif dengan konsentrasi $17 \%$. Keberadaan $\mathrm{HCl}$ dengan konsentrasi yang cukup pekat dapat menghilangkan noda pada toilet, permukaan porselen, keramik, mosaik dan sejenisnya.

Pada penelitian ini dilakukan eksperimen untuk menghasilkan gas hidrogen melalui reaksi berbagai logam dengan cairan pembersih lantai dengan merek WPC dan Vixal.

\section{Metodologi Penelitian}

2.1. Alat dan Bahan,

Alat yang digunakan pada penelitian ini adalah wadah plastik, botol kaca bekas, balon, gelas ukur, neraca, dan gunting. Bahan yang digunakan pada penelitian ini adalah cairan 
pembersih lantai merek WPC dan Vixal, akuades, karet gelang, aluminium foil, seng, besi, dan tembaga.

\subsection{Prosedur penelitian}

Sebanyak $50 \mathrm{~mL}$ cairan pembersih lantai merek WPC dimasukkan ke dalam 4 botol kaca bekas. Kemudian, ke dalam masing-masing botol dimasukkan 0,91 g Logam Al, Logam Zn, Logam $\mathrm{Cu}$ dan Logam Fe. Tutup botol dengan balon dan ikat dengan menggunakan karet gelang. Kemudian, biarkan reaksi terjadi selama 20 menit. Prosedur yang sama dilakukan untuk cairan pembersih lantai merek Vixal.

\section{Hasil dan Diskusi}

\subsection{Analisis hasil Pengamatan}

Cairan pembersih lantai merk WPC dan Vixal mengandung $17 \% \mathrm{HCl}$. $\mathrm{HCl}$ atau Asam Klorida merupakan asam Arhenius dan termasuk sebagai asam kuat. $\mathrm{HCl}$ bereaksi dengan logam menghasilkan gas hidrogen. Reaksi yang terjadi merupakan reaksi oksidasi sebagai berikut:

$$
\begin{aligned}
& \mathrm{Zn}_{(\mathrm{s})}+2 \mathrm{HCl}_{(\mathrm{aq})} \rightarrow \mathrm{ZnCl}_{2(\mathrm{aq})}+2 \mathrm{H}_{2(\mathrm{~g})} \\
& \mathrm{Al}_{(\mathrm{s})}+3 \mathrm{HCl}_{(\mathrm{aq})} \rightarrow \mathrm{AlCl}_{3(\mathrm{aq})}+3 \mathrm{H}_{2(\mathrm{~g})} \\
& \mathrm{Fe}_{(\mathrm{s})}+3 \mathrm{HCl}_{(\mathrm{aq})} \rightarrow \mathrm{FeCl}_{3(\mathrm{aq})}+3 \mathrm{H}_{2(\mathrm{~g})} \\
& \mathrm{Cu}_{(\mathrm{s})}+2 \mathrm{HCl}_{(\mathrm{aq})} \rightarrow \mathrm{CuCl}_{2(\mathrm{aq})}+2 \mathrm{H}_{2(\mathrm{~g})}
\end{aligned}
$$

Kedua cairan pembersih lantai merk WPC dan Vixal mempunyai ciri berwarna biru. Cairan ini meupakan sabun yang mengandung asam kuat, sehingga saat berlangsungnya reaksi muncul gelembung-gelembung (buih) sabun seperti yang terlihat pada Gambar 1 dan Gambar 3. Kandungan $\mathrm{HCl}$ pada kedua cairan tergolong pekat $(\mathrm{HCl} 17 \%)$, sehingga saat logam masuk ke dalam cairan, langsung bereaksi hebat secara eksotermik ditandai dengan munculnya gelembung-gelembung gas di sekitaran logam dan panas yang menyelimuti dinding botol kaca.

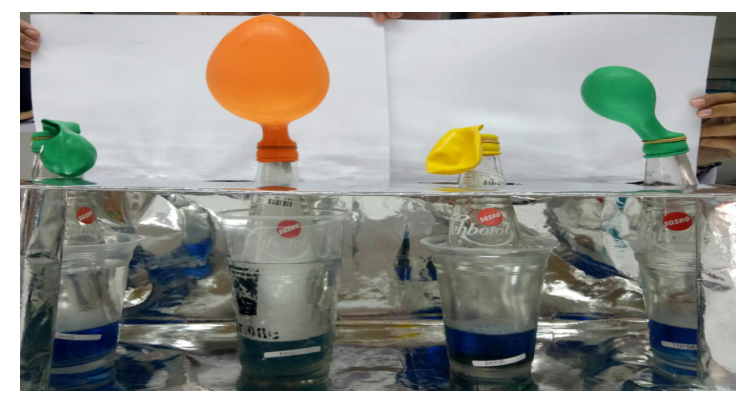

Gambar 1. Hasil Reaksi Logam dengan Cairan Pembersih Lantai WPC

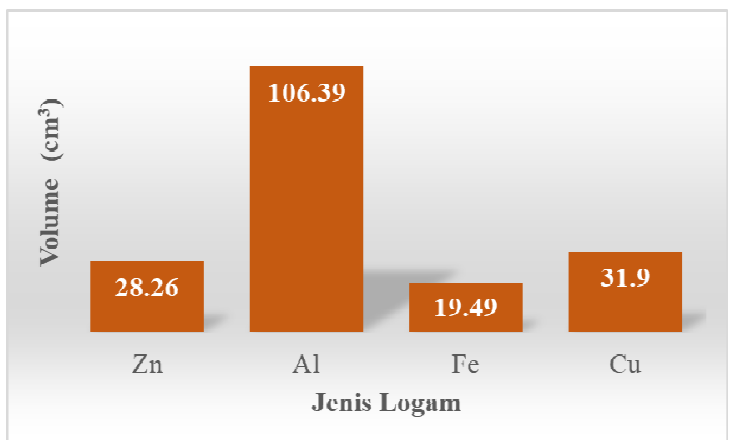

Gambar 2. Diagram Volume Gas Hidrogen (Cairan Pembersih Lantai WPC)

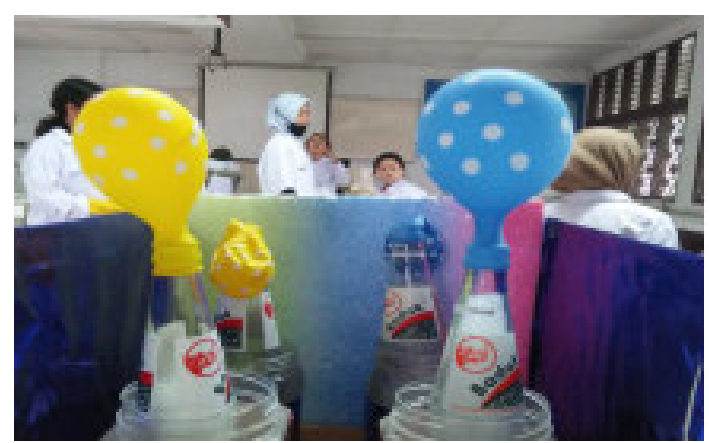

Gambar 3. Hasil Reaksi Logam dengan Cairan Pembersih Lantai Vixal

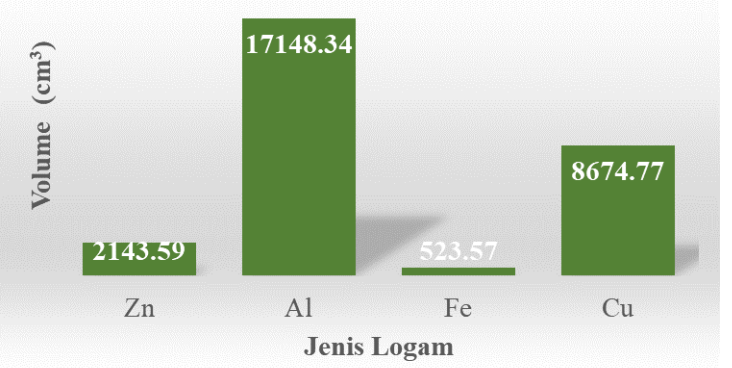

Gambar 4. Diagram Volume Gas Hidrogen (Cairan Pembersih Lantai Vixal)

Berdasarkan data pada Gambar 2 dan Gambar 4 pada kedua jenis cairan pembersih (WPC dan Vixal), gas hidrogen yang dihasilkan paling banyak adalah hasil reaksi cairan pembersih lantai dengan logam Al. Aluminium merupakan logam dengan potensial reduksi $\mathrm{E}^{0}=-1,66$ Volt. Rendahnya potensial reduksi $\mathrm{Al}$ menyebabkan $\mathrm{Al}$ sangat mudah bereaksi dengan asam kuat $\mathrm{HCl}$.

Volume gas hidrogen yang dihasilkan pada cairan pembersih lantai Vixal lebih banyak jika dibandingkan dengan WPC. Namun, kedua cairan menunjukkan trend yang sama, yakni urutan volume gas hidrogen yang dihasilkan pada kedua cairan adalah $\mathrm{Al}>\mathrm{Cu}>\mathrm{Zn}>\mathrm{Fe}$. Berdasarkan data potensial sel $\left(\mathrm{E}_{\text {red }}^{\mathrm{o}}\right)$ urutan logam yang paling 
mudah bereaksi dengan zat asam adalah $\mathrm{Al}>\mathrm{Zn}>\mathrm{Fe}>\mathrm{Cu}$ sesuai dengan Tabel 1 .

Tabel 1. Data Potensial Reduksi (Brown, Theodore L., et al $)^{5}$

\begin{tabular}{|l|l|}
\hline $\mathrm{E}_{\text {red }}^{\mathrm{r}}($ Volt) & Reaksi Reduksi \\
\hline$-1,66$ & $\mathrm{Al}^{3+}{ }_{(\mathrm{aq})}+3 \mathrm{e}^{-} \rightarrow \mathrm{Al}_{(\mathrm{s})}$ \\
\hline$-0,76$ & $\mathrm{Zn}^{2+}{ }_{(\mathrm{aq})}+2 \mathrm{e}^{-} \rightarrow \mathrm{Zn}_{(\mathrm{s})}$ \\
\hline$-0,44$ & $\mathrm{Fe}^{2+}{ }_{(\mathrm{aq})}+2 \mathrm{e}^{-} \rightarrow \mathrm{Fe}_{(\mathrm{s})}$ \\
\hline$+0,34$ & $\mathrm{Cu}^{2+}{ }_{(\mathrm{aq})}+2 \mathrm{e}^{-} \rightarrow \mathrm{Cu}_{(\mathrm{s})}$ \\
\hline
\end{tabular}

Berdasarkan data pada Tabel 1, urutan volume gas hidrogen yang seharusnya dihasilkan adalah $\mathrm{Al}>\mathrm{Zn}>\mathrm{Fe}>\mathrm{Cu}$. Namun, berdasarkan data pada Gambar 2 dan Gambar 4 menunjukkan fenomena yang berbeda. Faktor luas permukaan logam mempengaruhi hasil produksi gas hidrogen yang dihasilkan. Semakin besar luas permukaan logam, semakin cepat reaksi terjadi dan semakin banyak gas hidrogen yang dihasilkan. Sehingga dapat disimpulkan bahwa ketidakseragaman ukuran logam yang digunakan pada penelitian ini mempengaruhi trend hasil produksi gas hidrogen pada kedua cairan pembersih lantai tersebut.

\section{Kesimpulan}

Cairan pembersih lantai mengandung 17\% $\mathrm{HCl}$ dan dapat bereaksi dengan logam menghasilkan gas hidrogen. Gas hidrogen paling banyak dihasilkan adalah reaksi antara logam $\mathrm{Al}$ dengan cairan pembersih lantai (WPC dan Vixal) karena potensial reduksi Al sangat rendah sehingga sangat mudah bereaksi dengan asam kuat. Trend yang sama ditunjukkan pada kedua cairan pembersih lantai untuk jumlah gas hidrogen yang dihasilkan yaitu $\mathrm{Al}>\mathrm{Cu}>\mathrm{Zn}>\mathrm{Fe}$ karena luas permukaan logam yang digunakan tidak seragam.

\section{Referensi}

1. Holladay J.D., Hu, J., King, D. L.., Wang, Y., (2009). "An overview of hydrogen production technologies." Cat. Today. 139, 244-260.

2. Ahmed, S. A. S., et al., (2015). "Production of Hydrogen from Industrial Metal Waste." Egypt. J. Chem. 58(5), pp. 555-561.

3. Soler, L., et al. (2009). "In situ generation of hydrogen from water by aluminum corrosion in solutions of sodium aluminate." J. Power Source, 192, pp. 21-26.

4. Wang, H.Z., et al. (2009). "A review on hydrogen production using aluminum and aluminium alloys." Renew \& Sustainable Energy Rev. 13, pp. 845-853.

5. Brown, Theodore L., et al. (2015). Chemistry: The Central Science (13 ${ }^{\text {th }}$ Edition). New Jersey: Pearson Education Inc. 